\title{
REVIEW
}

\section{Induced pluripotent stem cell-derived vascular smooth muscle cells}

\author{
Makeda Stephenson', Daniel H Reich² and Kenneth R Boheler1 \\ 'Department of Biomedical Engineering, The Johns Hopkins University, Baltimore, Maryland, USA \\ 2Department of Physics and Astronomy, The Johns Hopkins University, Baltimore, Maryland, USA
}

Correspondence should be addressed to K R Boheler: kbohele1@jhmi.edu

\begin{abstract}
The reproducible generation of human-induced pluripotent stem cell (hiPSC)-derived vascular smooth muscle cells (VSMCs) in vitro has been critical to overcoming many limitations of animal and primary cell models of vascular biology and disease. Since this initial advance, research in the field has turned toward recapitulating the naturally occurring subtype specificity found in VSMCs throughout the body, and honing functional models of vascular disease. In this review, we summarize vSMC derivation approaches, including current phenotype and developmental origin-specific methods, and applications of VSMCs in functional disease models and engineered tissues. Further, we discuss the challenges of heterogeneity in hiPSC-derived tissues and propose approaches to identify and isolate vSMC subtype populations.
\end{abstract}

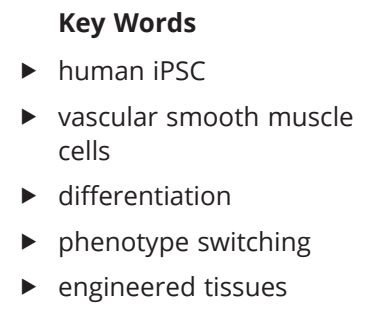

\section{Introduction}

Vascular smooth muscle cells (vSMCs) develop from cell lineage precursors and progenitors to form a layer of non-striated contractile mural cells located between the tunica media and tunica adventitia of blood vessels which stabilize and provide mechanical strength to the endothelial layer (1). Once formed, vSMCs retain considerable plasticity and display a range of phenotypes that vary from synthetic (proliferative, extracellular matrix (ECM) producing and reparative) to contractile (force generating) $(2,3)$. Functionally, vSMCs mediate vessel tone to regulate blood flow (4), provide signals during inflammation that support immunological function (5), and are involved in cell replacement and tissue repair. vSMC dysfunction can lead to vascular complications or disease, which contribute significantly to morbidity and mortality, particularly with aging $(6,7)$. While animal models and primary human vSMC culture systems have contributed to our understanding of vascular biology, significant differences in the vascular physiology between rodents and humans, inadequate access to patient-derived vSMCs, and the lack of well-defined patient-specific 3D tissue models that provide a closer approximation of the in vivo environment currently limit research progress.

Human (h)-induced pluripotent stem cell (iPSC)derived vSMCs represent an alternative system for human vascular studies (8). Human iPSCs, generated from patient-derived somatic cells, are able to differentiate into almost any cell type and can serve as an unlimited cell source for disease modeling, drug screening and tissue engineering. Although promising, significant hurdles remain that will likely affect experimental and ultimately therapeutic outcomes. Most differentiating cultures of hiPSCs contain phenotypically and developmentally diverse vSMCs, ranging from synthetic to contractile, and non-vSMCs in variable proportions. Although strategies to enrich lineage-specific or contractile vSMCs from non-vSMCs have met with some success, most published studies have relied on differentiated vSMCs of undefined

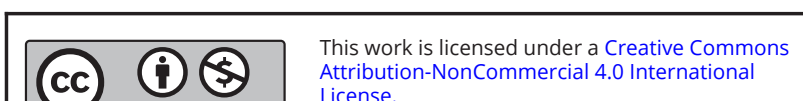
Attribution-NonCommercial 4.0 International ( 
embryonic origin, purity, maturation state or functional phenotype. In this review, we discuss the differentiation and lineage commitment of vSMCs derived from hiPSCs, their maturation and phenotypic state, applications in pharmacological testing, functional testing, disease modeling and development of bioengineered models to transcend current experimental and therapeutic limitations.

\section{Human iPSC-derived vSMCs}

\section{Differentiation and purification}

The establishment of in vitro differentiation systems to produce hiPSC-vSMCs evolved from both iterative in vitro and marker-driven studies developed from diverse mammalian systems. Based on pioneering work with murine $(\mathrm{m})$ and human embryonic stem cells (ESCs) (9, $10,11,12,13,14)$, Taura et al. were the first to report the generation of mural cells (vSMCs and pericytes) from hiPSC lines (15). Using a protocol established for hESCs, they successfully differentiated hiPSCs into vascular-endothelial cadherin (CDH5)-positive and -negative cells. With continued differentiation, vascular cells that expressed both $\alpha$-smooth muscle actin (ACTA2) and calponin 1 (CNN1) (see Table 1 for informative markers) could be derived from CDH5-negative cells. The differentiation efficiency of hiPSC to mural cells was comparable to that from hESCs. Lee et al. created the first hiPSC lines derived from somatic cells of vascular origin (16). Using a nonspecific embryoid body (EB) cell aggregation method (Fig. 1) followed by cultivation in SMC-specific medium, the hiPSC lines generated in this study could differentiate into smooth muscle-like cells with morphologies that were similar to human aortic vSMCs in terms of gene expression patterns, vascular cell markers (e.g., ACTA2), epigenetic states of pluripotency-related genes (e.g.,
OCT4), and in vitro functional properties (calcium movements in response to membrane depolarization and collagen gel contraction in response to vasoconstrictors). Based on these and other differentiation studies, a number of approaches were subsequently developed to enrich for functional SMCs from hiPSCs and precursor cells in vitro. Ge et al. described a method that yielded SMCs that were $>95 \%$ CNN1+ but which were likely of mixed origin (17). Lin et al. described how hiPSC-derived vSMCs could be purified using antibodies to activated leukocyte cell adhesion molecule (ALCAM/CD166)-negative cells to exclude cardiomyocytes and to yield cultures of $>90 \%$ ACTA2+ SMCs. They also showed that use of antibodies to negatively select for the endothelial marker CD31 could yield $>95 \%$ pure SMC populations (18). Lactate-based metabolic selection techniques have further improved the purity of vSMCs without cell sorting (19). Despite these advances in vSMC differentiation and purification, the vSMC progeny derived from hiPSCs were usually of unknown lineage origin or contractile function.

\section{Differentiation of lineage-specific vSMCs}

Developmentally, vSMCs are derived predominantly from mesoderm (20) and secondarily from neuroectoderm (neural crest, NC) cell lineages (Table 2) $(21,22)$. Studies of lineage commitment from hPSCs (i.e., hESCs and hiPSCs) based on mesoderm and neuroectoderm markers have been critical to defining the cellular origins of vSMCs. Brachyury/T-box transcription factor T (TBXT), an early primitive streak marker of nascent mesoderm, is upregulated during early in vitro differentiation of murine ESCs. Differentiating mESCs that express TBXT give rise to hematopoietic, vascular and cardiac cell lineages in a temporal-defined pattern $(7,23)$. Kouskoff et al. subsequently showed that $\mathrm{TBXT}^{+}$precursor cells that also express the fetal liver kinase-1 receptor

Table 1 Informative markers of vSMC differentiation and phenotype switching. Taken together, these markers are considered indicative of vascular smooth muscle differentiation (91). Although not individually unique to vSMCs, the relative expression of these markers can be indicative of the cell's phenotype, which can range from synthetic to contractile. The most definitive SMC markers are highlighted with an superscript a; however, these are not specific to vSMCs. Markers like TAGLN are expressed in SMCs and fibroblasts, while ACTA2 is expressed in both vSMCs and non-vSMCs (e.g., myofibroblasts, early cardiomyocytes).

\begin{tabular}{l} 
Marker \\
\hline$\alpha$-Smooth Muscle Actin (ACTA2) \\
Transgelin (TAGLN/SM22a) \\
Calponin (CNN1) \\
Smooth muscle Myosin Heavy Chain (MYH11)a \\
Smoothelin (SMNT)a
\end{tabular}

\begin{tabular}{l} 
Early/synthetic phenotype \\
\hline $\mathrm{HE}$ \\
$\mathrm{HE}$
\end{tabular}

HE, high expression; M/LE, medium/low expression. https://vb.bioscientifica.com

https://doi.org/10.1530/VB-19-0028 (c) 2020 The authors Published by Bioscientifica Ltd

\begin{tabular}{l} 
Late/contract \\
\hline $\mathrm{M} / \mathrm{LE}$ \\
$\mathrm{M} / \mathrm{LE}$ \\
$\mathrm{HE}$ \\
$\mathrm{HE}$ \\
$\mathrm{HE}$ \\
B $\$$ \\
BY NC
\end{tabular}

This work is licensed under a Creative Commons Attribution-NonCommercial 4.0 International License. ded from Bioscientifica.com at 04/26/2023 11:42:04AM 

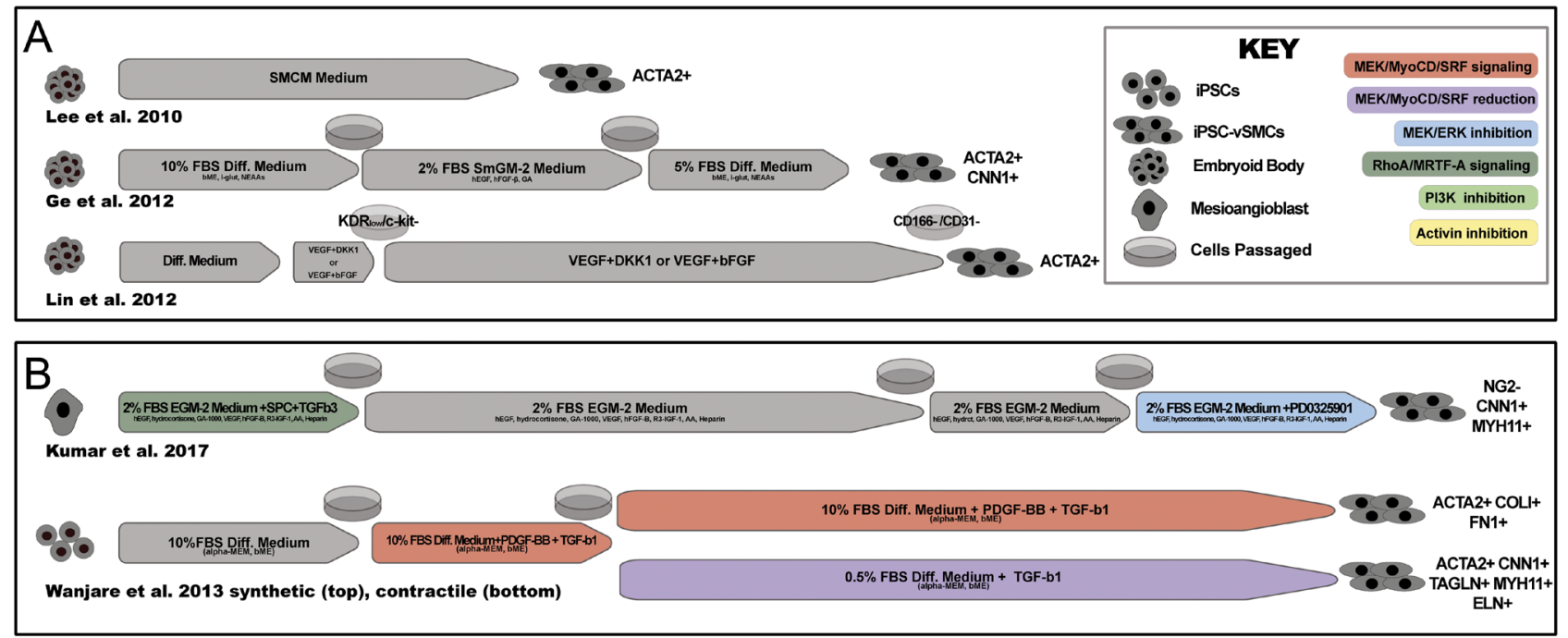

\section{Figure 1}

Scaled, graphical summary of selected iPSC-vSMC differentiation protocols. (A) Non-specific differentiation protocols are initiated after formation of an embryoid body (EB) and feature limited vSMC marker characterization. EB differentiation is generally non-directed, but specific cell types can be induced depending on the addition of growth factors at specific times of cultivation $(16,17,18)$. (B) Phenotype-driven protocols seek to generate either synthetic or contractile vSMCs through phenotype switching. Cell assessment is made in part through monitoring the formation of contractile structures within cells and levels of MYH11 (30,37). (C) Lineage-specific differentiation is achieved by way of mesodermal or neuroectoderm intermediates and results in neural crest (NC), lateral plate mesoderm (LPM) or paraxial mesoderm (PM) cell populations (34). Selected pathway targets have been highlighted. The time of cultivation for all of the listed protocols is indicated longitudinally at the bottom of (C) in days. SMCM. smooth muscle cell medium; EGM-2, endothelial growth medium 2; SmGM-2, smooth muscle cell growth medium 2; CDM, chemically defined medium; BME, $\beta$-mercaptoethanol; MEM, minimal essential medium; NEAA, non-essential amino acids; EGF, epidermal growth factor; VEGF, vascular endothelial growth factor; FGF2/bFGF, fibroblast growth factor 2; SPC, sphingosylphosphorylcholine; DKK1, Dickkopf 1; PDGF, platelet-derived growth factor; TGF- $\beta 1$, transforming growth factor beta 1; FBS, fetal bovine serum; ACTA2, $\alpha$-smooth muscle actin; CNN1, calponin 1; MYH11, smooth muscle myosin heavy chain; NG2, neuron-glial antigen 2; COLI, collagen I; FN1, fibronectin 1; TAGLN, transgelin; ELN, elastin; GA-1000, Gentamicin sulfate-Amphotericin; CD31/PECAM, platelet endothelial cell adhesion molecule; CD166/ALCAM, CD166 antigen or activated leukocyte cell adhesion molecule.

(KDR) preferentially give rise to SMCs (24). Since $\mathrm{KDR}^{+}$ progenitors from hESCs retain the capacity to generate colonies that display hematopoietic, cardiac and vascular potential, the developmental pattern of these markers appears to be highly conserved across mammalian species and within lines of hESCs $(25,26,27)$. Patsch et al. showed that canonical Wnt activation (by glycogen synthase kinase 3 inhibition) and bone morphogenic protein 4 (BMP4) supplementation could rapidly commit hPSCs to a mesodermal fate. In their experiments, maximal TBXT levels were observed within 3 days of hPSC differentiation. Exposure to activin A and plateletderived growth factor subunit B (PDGFB) promoted the differentiation of $\mathrm{TBXT}^{+}$cells into vSMCs that were almost exclusively PDGF receptor B (PDGFRB) positive. Gene transcripts, metabolomic profiles and functional properties (contractile responsiveness to endothelin 1 and carbachol) of PDGFRB ${ }^{+}$vSMCs were generally consistent with those generated from primary vSMCs (28). Vodyanik et al. developed a lineage tree of specific markers of hPSC-derived progenitor cells to temporally define cells that generate mesoderm-derived SMCs. These authors demonstrated that the onset of vasculogenesis from hPSCs develops sequentially from primitive posterior mesoderm-derived mesenchymoangioblast (MB) precursors which are positive for both the Apelin receptor

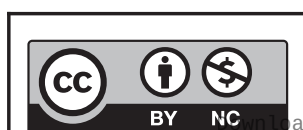

This work is licensed under a Creative Commons Attribution-NonCommercial 4.0 International License. ded from Bioscientifica.com at 04/26/2023 11:42:04AM 


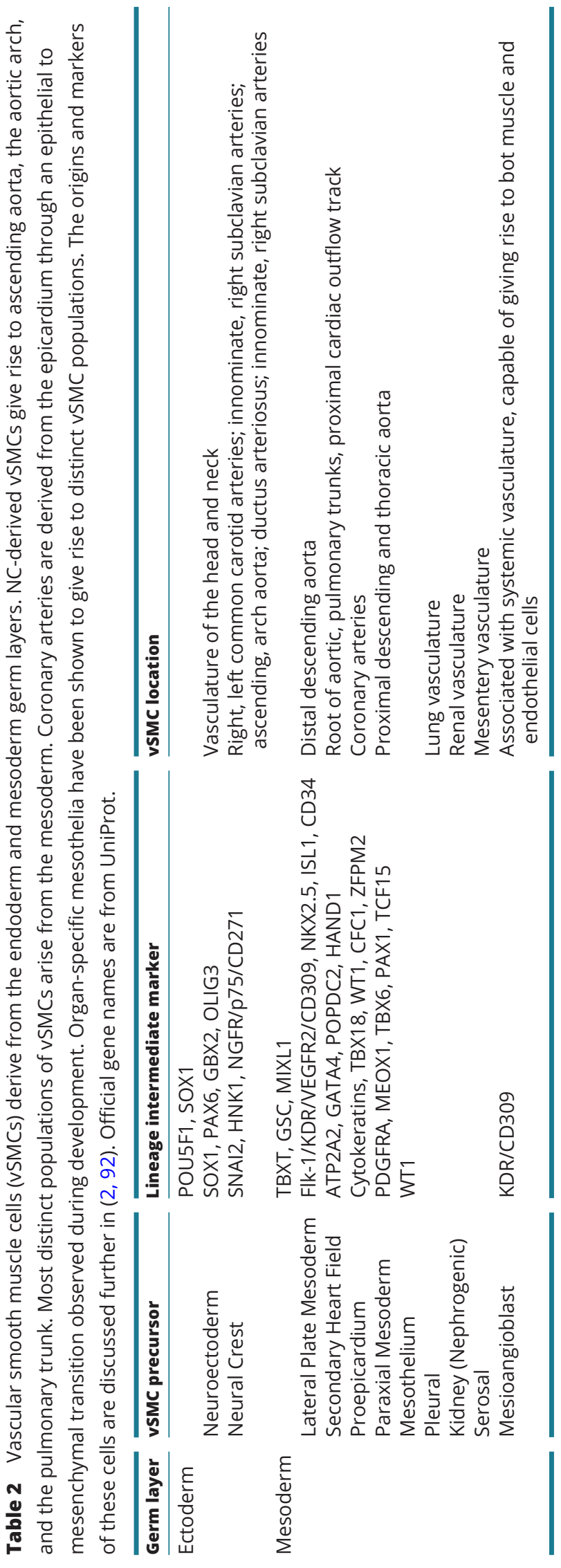

https://vb.bioscientifica.com https://doi.org/10.1530/VB-19-0028
(APLNR) and the PDGFA receptor (29). MB cells could also be induced to differentiate into primitive PDGFRB $^{+}$ CD271+ ${ }^{+}$CD73- mesenchymal progenitors that give rise to proliferative pericytes, SMCs, and mesenchymal stem/stromal cells (30). Addition of transforming growth factor $\beta 3$ (TGF $\beta 3$ ) and sphingosylphosphorylcholine directed these mesenchymal progenitors into immature, synthetic-like SMCs expressing ACTA2 and CNN1.

The lineage tree of neural crest (NC) stem cells that give rise to vSMCs is less well defined than that of mesodermal lineages. Developmentally NC cells are derived at the border of the neural and non-neural ectoderm. Consequently, NC cells are heterogeneous and contribute to the formation of multiple cell types including peripheral neurons, glial cells and SMCs. Vascular SMCs derived from NC are critical to the formation of the ascending aorta, the aortic arch, and the pulmonary trunk (Table 2). In vitro, hESC-derived NC stem cells (NCSCs) can differentiate into both neural and mesenchymal lineages. These hESC progenitors can be isolated and purified by sorting for neurotrophin growth factor receptor (p75)positive cells $(31,32)$. Continued differentiation and sorting with CD73 and neural cell adhesion molecule (NCAM) permit the isolation of transgelin (TAGLN/ SM22 $\alpha$ )-positive SMCs. Wang et al. subsequently showed that TGF- $\beta 1$ induction of hiPSC-derived NCSCs positive for nestin, vimentin, human natural killer-1 (HNK1) carbohydrate, and zinc-finger protein Snai1 also gave rise to vSMCs (33).

Taking advantage of these and other cell lineage markers, Cheung et al. developed reliable methods to differentiate hPSCs into lineage-specific vSMCs $(34,35)$. They showed that early mesoderm differentiation could be initiated in monolayers of hPSCs using chemically defined medium (CDM), containing polyvinyl alcohol (PVA), fibroblast growth factor (FGF)-2, LY294002 (an inhibitor of phosphoinositide 3-kinases (PI3K)), and BMP4 for 1.5 days. Either lateral plate mesoderm (LPM) or paraxial mesoderm (PM) could then be induced by supplementing CDM-PVA medium with FGF2 and BMP4 or with FGF2 and LY294002 for 3.5 days, respectively (Fig. 1). For differentiation to NC lineages, Cheung et al. cultivated hPSCs in CDM-PVA medium supplemented with FGF and SB431542 (an ALK5 TGF- $\beta$ /Activin/Nodal pathway inhibitor) for 7 days. By inducing specific cell lineage precursors that could be monitored by markers (LPM: KDR, NKX2-5, ISL1; PM: TCF15, TBX6, MEOX; and NC: PAX6, Nestin, GBX2; Table 2), lineage-specific SMCs could be generated by supplementing these precursors with platelet-derived growth factor (PDGF)-BB and TGF- $\beta 1$

(c) 2020 The authors Published by Bioscientifica Ltd 
in defined medium for 6 days, followed by cultivation in SMC-specific medium. The resulting vSMCs from all these lineages generally have spindle-shaped morphologies, particularly at high densities (Fig. 2), and express TAGLN, CNN1, and smooth muscle myosin heavy chain (MYH11). In our experiments, we find that the presence of MYH11 often varies among batches of differentiated progeny, particularly when derived from distinct hiPSC lines. The presence of other vascular markers (CNN1, TAGLN) also exhibit some minor cell-to-cell and batchto-batch variability (Fig. 2, bottom row). Cheung et al. and others went on to demonstrate the impact of embryological origin on vSMC structural properties and disease response. They demonstrated that lineagespecific vSMCs demonstrated differential expression of matrix metallopeptidase-9 (MMP9) and tissue inhibitor of metallopeptidase-1 both in hPSC-derived vSMCs and in primary cells (34). Jiao et al. demonstrated that vSMC subtypes also display differential proteolytic abilities in some disease models (36), which are likely involved in disease progression (see below). These findings suggest that in vitro experimental outcomes depend in part on the lineage origin of vSMCs. Further, the results suggest that the anatomically localized incidence of aortic dissections may be affected by the developmental origin of vSMCs.

\section{vSMC maturation and phenotype switching}

Fully differentiated hPSC-derived vSMCs like their endogenous counter-parts exhibit phenotype switching and transition between an immature synthetic phenotype to a more mature contractile vSMC phenotype (Fig. 1). By monitoring the expression of MYH11 and elastin, Wanjare et al. demonstrated that the presence of synthetic versus contractile phenotypes from different hiPSC lines could be regulated in vitro by PDGF-BB, TGF- $\beta 1$ and the concentration of fetal bovine serum (FBS) (37). Specifically, cultivation in low serum $(0.5 \%$ FBS $)$ with PDGF-BB deprivation caused the formation of the contractile SMC phenotype in which MYH11 was elevated. Contractile vSMCs when compared to synthetic vSMCs were characterized by a more condensed cell morphology, more prominent filamentous arrangements of cytoskeletal proteins, robust formation of endoplasmic reticulum, more numerous and active caveolae as well as enhanced contractility $(37,38$, 39 , 40). Alternatively, cultivation of these cells in high serum (10\% FBS) supplemented with both PDGF-BB and TGF- $\beta 1$ successfully induce the synthetic SMC phenotype with low levels of MYH11 protein and high levels of ECM proteins. Eoh et al. were able to use these defined cells to engineer more elastic and functional vascular smooth muscle tissue constructs (38). Kumar et al. demonstrated that inhibition of MEK signaling, which is required for the support of protein synthesis in SMCs and growth, could also promote maturation of immature SMCs. Treatment of immature vSMCs with the MEK inhibitor PD0325901 caused a decrease in overall proliferation, a more elongated, spindle shaped morphology and the upregulation of SMC markers, including MYH11 (30). Although it remains unclear whether all vSMCs derived
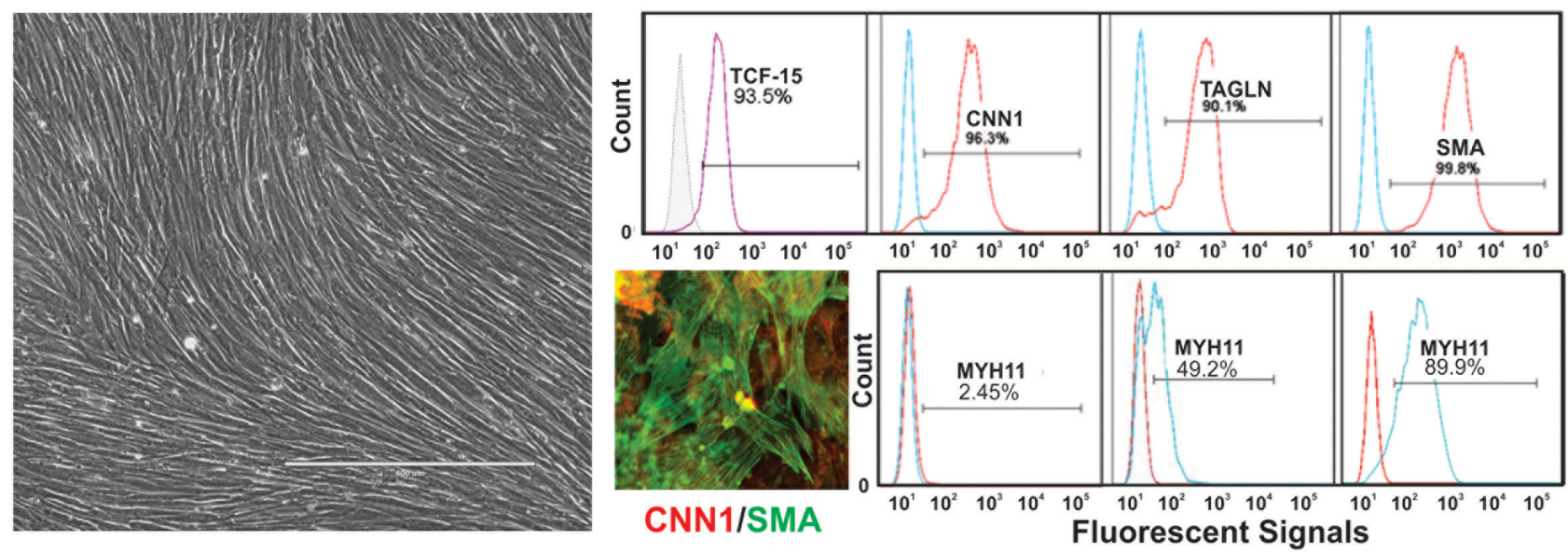

Figure 2

Differentiation of human iPSC line i057 to vSMCs generated via paraxial mesodermal (PM) intermediates. vSMCs derived from iPSCs through PM intermediates are shown here as a monolayer culture cultivated in $2 \%$ fetal bovine serum (FBS) (left) $(35,52)$. The presence of TCF-15-labeled intermediates at differentiation day 7, as well as markers (CNN1, TAGLN and SMA/ACTA2) of differentiated vSMC could be quantified by flow cytometry (top row). Examples showing cell-to-cell and batch-to-batch heterogeneity of vSMCs are shown using co-immunostaining of i057-vSMCs with antibodies to CNN1 and SMA (ACTA2), and by flow cytometry of MYH11 immunostained vSMCs from three independent experiments (right, bottom row).

https://vb.bioscientifica.com https://doi.org/10.1530/VB-19-0028 (c) 2020 The authors Published by Bioscientifica Ltd

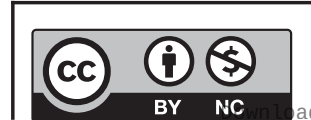

This work is licensed under a Creative Commons Attribution-NonCommercial 4.0 International License.

ded from Bioscientifica.com at 04/26/2023 11:42: 04AM 
either from diverse hiPSC lines (normal and diseased) or from different cell lineages undergo phenotype switching in response to MEK inhibition, the use of small molecules may prove to be one of the more effective ways of driving synthetic vSMCs to a contractile phenotype.

\section{Applications of vSMCs}

\section{Monolayers}

The use of hPSC-derived vSMCs in experimental biology has led to important advances in the study of human vascular development, pharmacological testing, and disease modeling. As just described, monolayer cultures proved critical to the development of robust differentiation protocols and to the generation of lineage-specific, phenotypically defined vSMCs (Fig. 1). With respect to pharmacological applications, Biel et al. established a number of hiPSC lines from hypertensive patients for pharmacogenomic studies (41). After differentiating the hiPSC lines via EB intermediates, they were able to examine the contractile response of TAGLN/ MYH11/myosin light chain/myosin light chain kinasepositive vSMCs to endothelin-1 and Phorbol 12-myristate 13-acetate. Traction force microscopy was employed to demonstrate that all the hiPSC-vSMCs tested had a measurable contractile response. They went on to show that addition of the pro-inflammatory chemokine tumor necrosis factor- $\alpha$ (TNF $\alpha$ ) induced the expression of C-X3-C Motif Chemokine Ligand 1 (CX3CL1) and MMP9 in these vSMCs, similar to what would be expected in vivo. However, the upregulation of these genes varied among the hiPSC line derived vSMCs. Despite some inconsistencies, all of the lines responded vectorially as expected, which led the authors to conclude that hiPSC lines generated from hypertensive patients would be of value to the analysis of pharmacogenomic responses.

In addition to cell contractile responses, monolayer cultures of vSMCs are useful for assessing calcium fluxes. Halaidych et al. generated vSMCs and analyzed intracellular calcium release and cellular contraction in response to the pharmacological vasoconstrictors endothelin-1, angiotensin II and carbachol (42). Using an automated quantification framework, they accurately described the functional phenotypes of hPSC-derived vSMCs generated using a variety of differentiation protocols $(34,37,40,43,44)$. From the hundreds of cells analyzed, they demonstrated that vSMCs display a high degree of functional heterogeneity, which may be attributable to genetic variation across hiPSC lines and to protocol differences in reprogramming and in vitro differentiation (45). Despite the observed heterogeneity, they concluded that their relatively high-throughput approach could overcome one of the major limitations for the use of vSMCs i.e. 'the lack of specific protein or genetic markers that distinguish perivascular cell types' in mixed cultures (42).

Cell-cell interactions (EC-vSMC; vSMC-vSMC; fibroblast-vSMC) can also be assessed in bilayer cultures. Collado et al. used RNA deep sequencing to compare the responses of iPSC-derived vSMC (via a neural crest intermediate) monolayers and of iPSC-derived EC and vSMC bilayers with bilayers made from primary cells under atheroprotective and athreroprone flow dynamics (as defined from patient data in specific regions of large vessels) (46). They found that genes related to migration, proliferation and inflammation increased when exposed to pathological flow or pharmacologic TNF $\alpha$ exposure, but not under healthy flow conditions relative to static conditions. This response was observed both in primary cell and stem cell-derived EC and vSMC bilayers. Responses between primary and iPSC-derived bilayers can therefore be recapitulated, at least in part, under both healthy and pathological flow conditions. These findings should facilitate future efforts to dissect how cell-cell interactions promote disease phenotypes.

Finally, cultures of hPSC-derived vSMCs have proven invaluable for the study and modeling of some disease processes. Examples include supravalvular aortic stenosis (SVAS) caused by mutations in elastin (17), congenital cardiovascular malformation (aortopathy) associated with bicuspid aortic valve (BAV) defects (36), Hutchinson-Gilford Progeria syndrome (HGPS) caused by defects in lamin A $(47,48)$, and Marfan's syndrome (MFS) caused by fibrillin mutations (44). Cerebral autosomal dominant arteriopathy with subcortical infarcts and leukoencephalopathy (CADASIL) caused by NOTCH3 mutations $(49,50)$ and cerebrovascular pathology in amyloid- $\beta$ metabolism (CAA) have also been modeled using hiPSC-derived vSMCs (51). The results of these studies have confirmed data from other mammalian systems, established new disease-related mechanisms and highlighted how the origin of vSMCs may contribute to disease processes. More specifically, Granata et al. found in hiPSC-derived vSMCs that mutations in fibrillin recapitulate many of the pathophysiological effects observed in patients with MFS and including defects in fibrillin-1 accumulation, ECM degradation, TGF- $\beta$ signaling, contraction and apoptosis. Kelleher et al. showed that hiPSC-derived mural cells were necessary for

This work is licensed under a Creative Commons Attribution-NonCommercial 4.0 International License. 
stabilizing capillary structures. In hiPSC-derived mural cells with NOTCH mutations (CADASIL), the cells had reduced PDGFB, decreased secretion of vascular endothelial growth factor (VEGF), and increased susceptibility to apoptotic insult (50). Moreover, these mutation-carrying mural cells could induce apoptosis of adjacent endothelial cells. The results with NC-derived mural cells thus provided novel insights into mechanisms responsible for this arteriopathy. Jiao et al. showed in a model of aortopathy that monolayer cultures of vSMCs derived from NC but not from PM lineages showed decreased contractile function concomitant with a decrease in overall MYH11 levels. These results underscore how lineage origins of vSMCs can affect disease progression (36). We have undertaken studies of vascular Ehlers-Danlos syndrome (vEDS) using monolayer cultures of hiPSC-vSMCs (52) and observed a number of RNA or protein changes in the presence of collagen binding proteins (integrins) and in some cell signaling pathways. VEDS, however, is a disease of the ECM caused by collagen III (COL3A1) mutations, which often lead to vascular dissections and aneurysms in patients. Since mature collagen fibril formation is extremely difficult to achieve in vitro, modeling of vSMCECM interactions with lesion formation is experimentally challenging in monolayer systems (53).

\section{Three-dimensional (3D) systems}

Although significant research advances have been achieved using traditional culture techniques, vSMC biology is modulated by environmental parameters and mechanical forces that are difficult if not impossible to recreate in monolayers. Consequently, engineered vascular tissues (eVTs), which can be used to model three-dimensional (3D) environmental interactions, are necessary to adequately assess physiologic and pathophysiologic vSMC behavior. The advantage of 3D culture has been demonstrated by experiments across a variety of cellular models which compare cells cultured in a 3D environment to those cultured in traditional monolayers. For example, focal adhesion kinase (FAK) and paxillin (PAX), two key integrin transducing signaling molecules, do not localize to the fibular adhesions formed in monolayer culture in the same manner as they do to the focal adhesions formed when fibroblasts are cultured in 3D (54). The integrin profile of cells cultured in monolayers also was shown to be significantly different than that of cells cultured in 3D environments. These findings, along with an understanding of differences in biomechanical force and transduction acting on cells in
$2 \mathrm{D}$ versus $3 \mathrm{D}$ environments (55) provide a theoretical framework for explaining observations that 2D culture impairs cell ability to secrete and organize ECM (56), transduce signals, respond to pharmacological agents and other stimuli, to mature, and generally to carry out normal physiological functions (57). Three-dimensional environments that approximate patent vessels are therefore prerequisites for improved evaluations of how pharmacologic, environmental or genetic factors affect vSMC biology in the context of a tissue.

In addition to providing insight to vSMC biology, eVTs represent a promising solution to the clinical challenge of treating vascular defects brought about due to trauma or disease. Current clinical approaches for vessel replacement generally require harvesting and grafting of autologous arteries and veins. However, patient-derived vessels may be affected by disease or advanced aging (58). As an alternative, immune-matched sources of implantable vasculature would be ideal. eVTs generated from patient-derived autologous hiPSCs represent one possible solution to this clinical problem. Currently, only a limited number of reports on hiPSC-derived vSMC eVTs have been published across both the basic research and preclinical medical device development literature. We summarize selected examples in Table 3. Most of these reports have focused on the technical details of achieving eVTs for pre-clinical applications as opposed to their utility in basic research.

A variety of fabrication approaches have been adapted to create eVTs targeted toward clinical translation, the technical details of which have been extensively reviewed elsewhere (59). Fabrication approaches employed in hiPSC-derived vSMC eVTs include wrapped sheets with aligned collagen fibrils for ECM-cell patterning (60), molding and casting with collagen production enhancing media for scaffold free tissue rings (43), electrospinning (38), and multi photon printing of heterotypic constructs (61). In one pre-clinical study, Hu et al. seeded vSMCs on 3D macroporous nanofibrous poly(l-lactide) scaffold, fabricated using porogen leaching techniques (62). These scaffolds could be implanted subcutaneously into immunodeficient mice. They found that the implanted vSMCs had uniform cell growth and that these cells promoted significant collagenous matrix deposition. Their results established a potentially efficient patientspecific approach for the use of hiPSC-derived vascular cells in the regeneration of vascular tissues in vivo.

A handful of heterotypic eVT examples of iPSCvSMCs cultured with ECs and/or CMs have been reported. Bargehr et al. showed that the embryonic origin of

This work is licensed under a Creative Commons Attribution-NonCommercial 4.0 International License. 


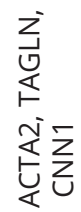
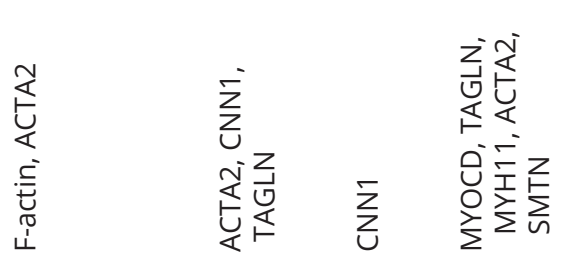

울

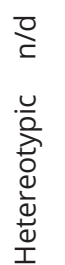

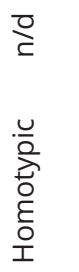

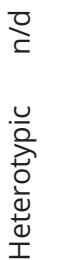

$\stackrel{2}{2}$
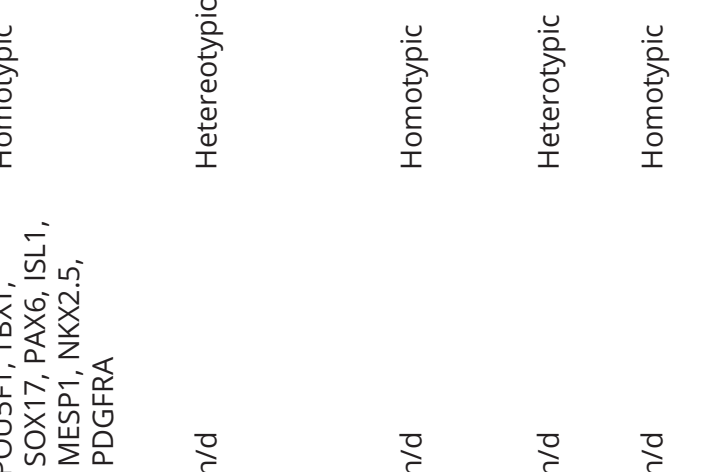

$$
\stackrel{2}{2}
$$

$$
\stackrel{2}{?}
$$$$
\text { 항 }
$$

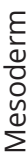

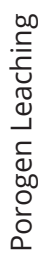
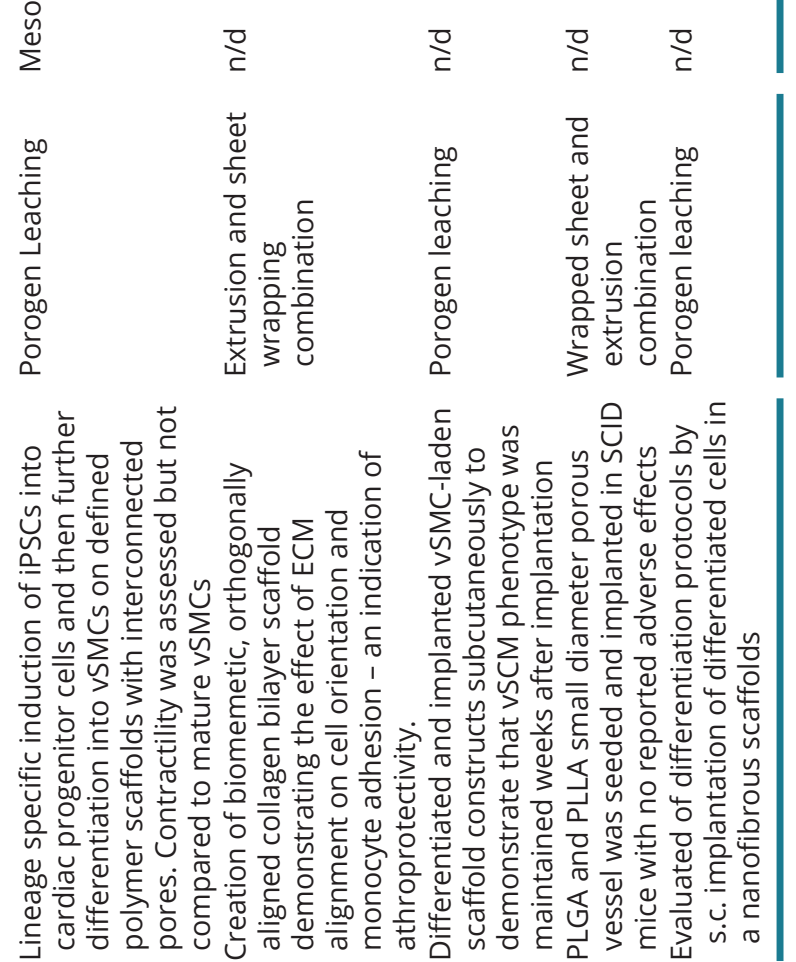

离。

은
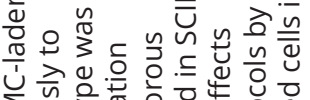$$
\text { 位 }
$$
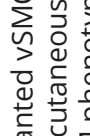

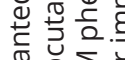
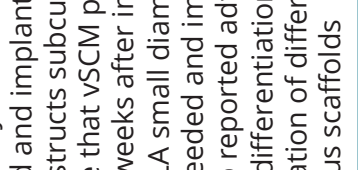

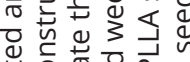

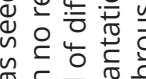

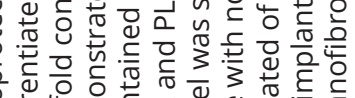

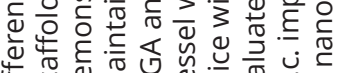

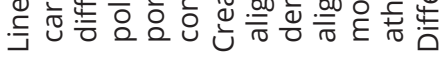

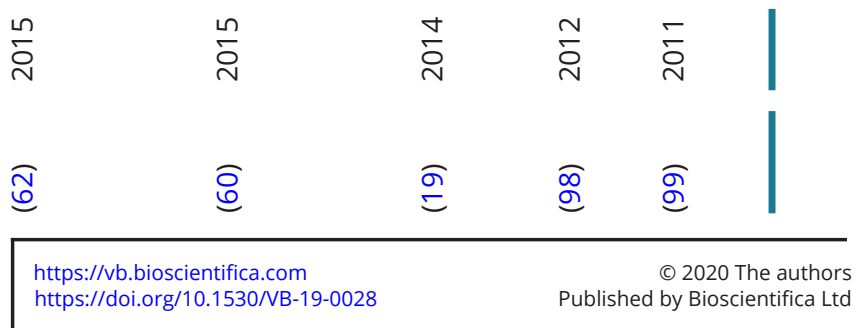

hESC-derived vSMCs also affected the ability of vSMCs to support human umbilical vein endothelial cells (HUVECs) network formation. LM-SMCs better supported EC network complexity and survival in vitro than either NC or PM-derived SMCs, suggesting that a lineage-specific approach coupled with ECs might be necessary for improved vascular tissue engineering and ultimately for therapeutic revascularization (63). Ren et al. reported the regeneration of functional pulmonary vasculature using decellularized rat and human lung scaffolds repopulated with hiPSCderived perivascular cells (PCs) that could give rise to vSMCs and hiPSC-ECs (64). They co-seeded decellularized rat lungs with ECs and/or PCs and found conditions that supported formation of both capillaries and larger vessels. When PCs were implanted onto decellularized human lung, they found that vascular lumen structures could also develop on these human matrices. Masumoto et al. generated 3D engineered cardiac tissues composed of cardiomyocytes, ECs and vascular mural cells derived from hiPSCs (65). Their engineered constructs displayed good in vitro structural maturation and electromechanical performance. When implanted into immune-tolerant rats following a myocardial infarction, the implants could regenerate myocardium within 4 weeks, suggesting that hiPSC-derived engineered tissues are capable of in vivo repair and regeneration. Additional proof-of-concept studies with heterotypic tissues have been reported with vSMCs and skeletal muscle (8).

In contrast with translational eVT approaches, lab-on-a-chip (LOC) devices have not been developed as surgically applicable constructs, but rather as highthroughput models that can be precisely manipulated and thoroughly interrogated to study cellular biology and cellcell interactions. These platforms are based on advanced microfabrication and microfluidic technologies and allow researchers to recreate complex biological systems in vitro (66). To date, most vascular engineering applications of LOCs have used ECs (67), but in 2017, Ribas et al. reported the use of a microfluidic LOC device to demonstrate that hiPSC-derived vSMCs from patients suffering from HGPS are significantly more susceptible to the effects of cyclic strain on a vessel than healthy cells (68). To demonstrate this, they created a device featuring a membrane over a chamber which could be evacuated, causing the membrane to bend outwards in a way that mimics the expansion of a vessel under pressure. By controlling the thickness of the membrane and the amount of vacuum applied, they were able to achieve precise amounts of stress on the cells cultured on the membrane, allowing them to mimic both physiological and pathological

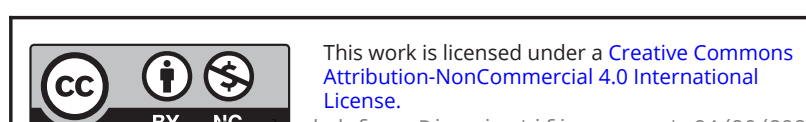


levels of stress. VSMCs in ECM were cultured on the membrane and fed by flowing media through their culture channel in a biomimetic manner. This device was designed to fit within a standard imaging slide and was transparent, allowing easy imaging of the tissue on a standard microscope. Using this system, they showed that biomimetic strain induced cell organization, and that pathological strain induced a similar phenotype to that of cells treated with angiotensin II, characterized by localization of superoxide production from the cytosol to the mitochondria. Further, a comparison of HGPS mutant vSMCs to healthy vSMCs under static, physiologic and pathological strain conditions demonstrated that HGPS cells have an exaggerated inflammatory and ECM binding response to strain (in some cases to both physiological and pathological strain) when compared to healthy cells. These findings provide insight into how the HGPS mutation changes cellular biology, in a manner that would not have been possible in a $2 \mathrm{D}$ culture system.

Cell-driven or 'bottom up' eVT fabrication, where cells are encouraged to assemble their own vasculature within a hydrogel, has been key to the development of LOC technology. This approach undergirds common models of microvasculature and tissue vascularization. VSMCs and pericytes stabilize the nascent vasculature in their role as support cells; however, to date, these methods have not been applied within the context of iPSC-derived vSMCs. Kusuma and colleagues described a vasculogenic model using iPSC-derived ECs $\left(\mathrm{VCad}^{+} / \mathrm{CD} 31^{+}\right)$and pericytes $\left(\mathrm{NG} 2^{+} / \mathrm{PDGFR}^{+}\right.$), a support cell which has been characterized as related but not equal to contractile vSMCs (69). They demonstrated that lumenized networks only formed within hyaluronic acid (HA) gels when unsorted cells were seeded together, and not in gels containing sorted cells. This finding supports the perspective that vasculogenesis and the maintenance of vasculature is an emergent function of endothelial cells together with mural cells and underscores the need for mass inclusion of vSMCs and pericytes in the development of physiological and pathological eVT models.

\section{Challenges of heterogeneity}

To increase standardization within the field and more faithfully recapitulate region-specific biology, population heterogeneity must be a primary consideration in the development of hiPSC-derived vSMC models. Biologists and tissue engineers must consider and report on both the embryological lineage and maturation state of cells used in constructs and seek to minimize the impact of interline variability on iPSC-derived vSMCs through careful experimental design. However, as indicated in Table 3, much of the field does not report on the purity, the phenotypic state or lineage specificity of their vSMCs or differentiation processes. Consequently, differences in experimental outcomes among lines are generally attributed to disease state without accounting for inherent heterogeneity among lines or phenotypic and developmental differences. Adding to the difficulty in understanding and reporting closely defined vSMCs is the fact that the phenotype is plastic and scalar. Cells generally present on a continuum between mature and immature phenotypes with variable degrees of proteolytic activity.

To reduce heterogeneity, additional protein or genetic markers are required to identify and isolate vSMCs with a defined phenotype and known developmental origin. Reduced cellular heterogeneity (i.e., isolated lineagespecific vSMCs with a synthetic or contractile phenotype and without contaminating non-vSMCs) would allow researchers to employ more rigorous experimental designs to confidently account for hiPSC interline variability (45) and promote meaningful interpretation of study results within and between groups. One validated approach that overcomes issues of cell heterogeneity and experimental variability is through immunophenotyping, which relies on the use of markers to classify cells with known traits. For live cell phenotyping, surface markers are usually required; however, accessible surface markers/proteins suitable for isolating phenotypically defined mature, live vSMCs are mostly lacking.

A number of approaches can be used to evaluate the surfaceome of vSMCs for live-cell phenotyping. These include the use of transcriptomics (70), antibody arrays, and both physical and affinity enrichment strategies coupled with proteomics (71). Transcriptomic approaches (microarrays and RNAseq) evaluating vSMCs generated by various in vitro differentiation protocols (34) have already led to a wealth of data that can be mined and compared with transcriptomic data from primary cell isolates. The use of single-cell RNAseq approaches to evaluate regionspecific vSMCs will be highly informative of cell-to-cell variations and for the identification of cell-surface markers within tissues $(72,73)$. For the latter, identification of potentially informative surface proteins can be facilitated through comparisons with data generated by Cunha et al. who bioinformatically generated a human cell surfaceome (74). There are, however, limitations with these approaches, because the presence of transcripts does

This work is licensed under a Creative Commons Attribution-NonCommercial 4.0 International License. 
not necessarily correlate with protein abundance on the cell surface (75). Moreover, transcriptomic data often fail to inform subcellular localization.

As an alternative, cell-surface capture (CSC) technology can be combined with high-resolution mass spectrometry to identify reliably informative cell-surface markers $(75,76,77)$. The advantages of this approach include the generation of experimental evidence that unequivocally confirms protein identity, localization to the cell surface, transmembrane orientation, and N-glycosite occupancy $(71,78)$. These experimental outputs promote antibody testing and development of new antibodies based on surface accessible epitopes for cell sorting, as well as the identification of likely drug targets that advance pharmacological screening and drug testing $(77,79)$. In unpublished work, we have already optimized experimental conditions and generated CSC libraries of lineage-specific PM-derived vSMC markers. As expected, a number of widely distributed integrin isoforms (ITGA2/3/4/5/6) were present on these vSMCs, but integrin isoforms such as ITGA11 and ITGA12 (and other markers) seem to be more restricted to vSMCs based on comparisons with the Cell Surface Protein Atlas (80). The methods that we employed for these cells, however, relied on older protocols where the labeling of 30-100 million cells is required. Newer protocols, auto-CSC (van Oostrom et al. Nat Comm, in press) and microCSC (personal communication, RL Gundry), will likely overcome this limitation and permit robust analysis of as few as 1-5 million cells and of primary vSMCs from different vessels. We predict that CSC together with complementary antibody arrays and bioinformatics approaches with transcriptomic datasets (79) will allow the discovery of specific proteins for characterizing vSMCs (phenotype and cell lineage) and for identifying proteins whose interactions with the ECM are known to affect the development of pathologies. The major limitations of immunophenotyping and cell sorting, however, are the reliability of antibodies, as these reagents often prove insufficient for cell sorting or are lacking altogether. Validated antibodies also are essential for the eventual isolation of GMP-qualified hiPSC-derived vSMCs for potential therapeutic applications.

In addition to the use of well-defined cells for regenerative medicine, non-invasive methods for monitoring vascular cell dynamics in eVTs both in vitro and in vivo will be required to ensure long-term viability. Raman spectroscopy is a non-destructive technique that provides detailed information about chemical structure and molecular interactions. This approach is based upon the interaction of light with chemical bonds in a material, and can provide marker-independent, molecular information on cell and tissue samples. Using primary vascular cells derived from different vessels, Marzi et al. determined that SMCs from different tissue origins exhibit unique spectral information when evaluated by Raman microspectroscopy (81). Each group of SMCs could be independently clustered as a function of tissue origin using multivariate data analysis (MVA). They also determined that Raman microspectroscopy could monitor phenotypic switching of cultured SMCs, which allowed them to assess the impact of culture conditions on ECM remodeling in tissue-engineered ring constructs. Based on these results, the authors speculated that Raman microspectroscopy and MVA will eventually be suitable for automated quality monitoring of stem cell and cell-based tissue engineering products with potential therapeutic applications.

\section{Future prospects and conclusions}

Vascular SMCs are integral in determining the mechanical (tonic) properties of the vascular wall (82), a function that is subverted in pathologies including vEDS, Marfan's syndrome, atherosclerosis and aneurysms. In vivo, vSMCs specifically respond to stretch and matrix stiffness to regulate contraction, but most approaches to address vascular tissue mechanics have largely been performed using animal models. While in vitro-derived vSMCs display functional mechanical properties in response to pharmacological agents, our current lack of understanding of how local tissue mechanics contribute to the formation in humans of vascular pathologies where local stresses exceed vascular wall strength limits our ability to prevent or non-invasively treat vessels subject to rupture (21, 83). Notably, in heritable conditions such as Marfan's syndrome (44) and vEDS $(84,85)$, which are amenable to modeling by iPSC-derived vSMCs, the mechanics of vSMC tissue is altered, sometimes dramatically, producing lifethreatening weaknesses and ruptures in arterial walls.

To develop high fidelity recapitulations of vascular biology which can be trusted to recreate in vivo behaviors, researchers will need to develop not just the mechanical or spatial functions of vasculature, but also the biological specificity observed within the body. It is critical that cells used in eVT constructs be appropriately selected based on in vivo observations of disease susceptibility and lineage origin matched to the anatomical region the construct is intended to model. This will require vSMCs from hiPSCs to be derived in an origin and phenotype specific manner.

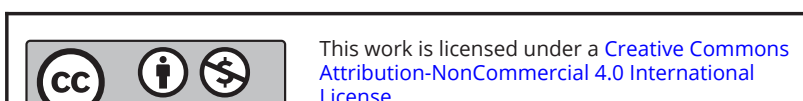
Attribution-NonCommercial 4.0 International

ded from Bioscientifica.com at 04/26/2023 11:42:04AM 
Currently, underreporting SMC functional heterogeneity is of particular consequence in iPSC-derived vSMCs eVT applications.

In conclusion, hiPSC-derived vSMCs represent a reproducible model system for basic vascular cell biology, pharmacology and translational research. When generated from patient-specific hiPSC lines, such as those from Marfan's disease or vEDS, these cells have the ability to provide new insights into the genetic basis of human vascular syndromes. More importantly, the development of reliable methods for the scalable generation and isolation of defined populations of SMCs from hiPSCs has potential applications for improving our understanding of disease mechanisms and for improving eVT fidelity for regenerative medicine. Lab-on-a-chip hiPSC-vSMC models consisting of immunophenotyped cells offer great potential for studies of local vascular tissue mechanics and associated disease processes using highly adaptable, small-scale constructs that can faithfully recapitulate vascular functional properties in 3D tissue-like structures $(86,87,88,89)$ or eVTs. When eVTs are coupled with measurements of vSMCs' force generation and interactions with the ECM (90), our understanding of how tissue mechanics and mechanotransduction influence vSMC contraction will likely lead to new mechanistic insights into how mechanics affect tissue function and disease development. Given the research advances over the past few years, we predict that well-defined hPSC-vSMCs will play an increasingly important and informative role for furthering research into genetic and injury-related vascular disease processes and ultimately in the development of translational medical approaches to treat vascular disease using eVT.

\section{Declaration of interest}

The authors declare that there is no conflict of interest that could be perceived as prejudicing the impartiality of this review.

\section{Funding}

This work was supported by a financial gift from the Huey Foundation to K R B and by an NSF Graduate Research Fellowship Program (NSF GRFP) award to M S.

\section{References}

1 Bergers G \& Song $\mathrm{S}$. The role of pericytes in blood-vessel formation and maintenance. Neuro-Oncology 20057 452-464. (https://doi. org/10.1215/S1152851705000232)
2 Majesky MW. Developmental basis of vascular smooth muscle diversity. Arteriosclerosis, Thrombosis, and Vascular Biology 200727 1248-1258. (https://doi.org/10.1161/ATVBAHA.107.141069)

3 Majesky MW, Dong XR, Regan JN \& Hoglund VJ. Vascular smooth muscle progenitor cells: building and repairing blood vessels. Circulation Research 2011108 365-377. (https://doi.org/10.1161/ CIRCRESAHA.110.223800)

4 Brozovich FV, Nicholson CJ, Degen CV, Gao YZ, Aggarwal M \& Morgan KG. Mechanisms of vascular smooth muscle contraction and the basis for pharmacologic treatment of smooth muscle disorders. Pharmacological Reviews 201668 476-532. (https://doi.org/10.1124/ pr.115.010652)

5 Lim S \& Park S. Role of vascular smooth muscle cell in the inflammation of atherosclerosis. BMB Reports 201447 1-7. (https:// doi.org/10.5483/bmbrep.2014.47.1.285)

6 Najjar SS, Scuteri A \& Lakatta EG. Arterial aging: is it an immutable cardiovascular risk factor? Hypertension 200546 454-462. (https:// doi.org/10.1161/01.HYP.0000177474.06749.98)

7 Boheler KR. Pluripotency of human embryonic and induced pluripotent stem cells for cardiac and vascular regeneration. Thrombosis and Haemostasis 2010104 23-29. (https://doi. org/10.1160/TH09-07-0507)

8 Klein D. iPSCs-based generation of vascular cells: reprogramming approaches and applications. Cellular and Molecular Life Sciences 2018 75 1411-1433. (https://doi.org/10.1007/s00018-017-2730-7)

9 Drab M, Haller H, Bychkov R, Erdmann B, Lindschau C, Haase H, Morano I, Luft FC \& Wobus AM. From totipotent embryonic stem cells to spontaneously contracting smooth muscle cells: a retinoic acid and db-cAMP in vitro differentiation model. FASEB Journal 1997 11 905-915. (https://doi.org/10.1096/fasebj.11.11.9285489)

10 Wobus AM, Guan K, Yang HT \& Boheler KR. Embryonic stem cells as a model to study cardiac, skeletal muscle, and vascular smooth muscle cell differentiation. Methods in Molecular Biology 2002185 127-156. (https://doi.org/10.1385/1-59259-241-4:127)

11 Sinha S, Hoofnagle MH, Kingston PA, McCanna ME \& Owens GK. Transforming growth factor-beta1 signaling contributes to development of smooth muscle cells from embryonic stem cells. American Journal of Physiology: Cell Physiology 2004287 C1560-C1568. (https://doi.org/10.1152/ajpcell.00221.2004)

12 Kolodziejska KM, Noyan-Ashraf MH, Nagy A, Bacon A, Frampton J, Xin HB, Kotlikoff MI \& Husain M. c-Myb-dependent smooth muscle cell differentiation. Circulation Research 2008102 554-561. (https:// doi.org/10.1161/CIRCRESAHA.105.162628)

13 Huang H, Zhao X, Chen L, Xu C, Yao X, Lu Y, Dai L \& Zhang M. Differentiation of human embryonic stem cells into smooth muscle cells in adherent monolayer culture. Biochemical and Biophysical Research Communications 2006351 321-327. (https://doi org/10.1016/j.bbrc.2006.09.171)

14 Hill KL, Obrtlikova P, Alvarez DF, King JA, Keirstead SA, Allred JR \& Kaufman DS. Human embryonic stem cell-derived vascular progenitor cells capable of endothelial and smooth muscle cell function. Experimental Hematology 201038 246-257.e1. (https://doi. org/10.1016/j.exphem.2010.01.001)

15 Taura D, Sone M, Homma K, Oyamada N, Takahashi K, Tamura N, Yamanaka S \& Nakao K. Induction and isolation of vascular cells from human induced pluripotent stem cells--brief report. Arteriosclerosis, Thrombosis, and Vascular Biology 200929 1100-1103. (https://doi.org/10.1161/ATVBAHA.108.182162)

16 Lee TH, Song SH, Kim KL, Yi JY, Shin GH, Kim JY, Kim J, Han YM, Lee SH, Lee SH, et al. Functional recapitulation of smooth muscle cells via induced pluripotent stem cells from human aortic smooth muscle cells. Circulation Research 2010106 120-128. (https://doi. org/10.1161/CIRCRESAHA.109.207902)

17 Ge X, Ren Y, Bartulos O, Lee MY, Yue Z, Kim KY, Li W, Amos PJ, Bozkulak EC, Iyer A, et al. Modeling supravalvular aortic stenosis syndrome with human induced pluripotent stem cells. 
Circulation 2012126 1695-1704. (https://doi.org/10.1161/ CIRCULATIONAHA.112.116996)

18 Lin B, Kim J, Li Y, Pan H, Carvajal-Vergara X, Salama G, Cheng T, Li Y, Lo CW \& Yang L. High-purity enrichment of functional cardiovascular cells from human iPS cells. Cardiovascular Research 201295 327-335. (https://doi.org/10.1093/cvr/cvs185)

19 Yang L, Geng Z, Nickel T, Johnson C, Gao L, Dutton J, Hou C \& Zhang J. Differentiation of human induced-pluripotent stem cells into smooth-muscle cells: two novel protocols. PLOS ONE $2016 \mathbf{1 1}$ e0147155. (https://doi.org/10.1371/journal.pone.0147155)

20 Iyer D, Gambardella L, Bernard WG, Serrano F, Mascetti VL, Pedersen RA, Talasila A \& Sinha S. Robust derivation of epicardium and its differentiated smooth muscle cell progeny from human pluripotent stem cells. Development 2015142 1528-1541. (https:// doi.org/10.1242/dev.119271)

21 Wagenseil JE \& Mecham RP. Vascular extracellular matrix and arterial mechanics. Physiological Reviews 200989 957-989. (https://doi. org/10.1152/physrev.00041.2008)

22 Wang G, Jacquet L, Karamariti E \& Xu Q. Origin and differentiation of vascular smooth muscle cells. Journal of Physiology 2015593 3013-3030. (https://doi.org/10.1113/JP270033)

23 Shalaby F, Ho J, Stanford WL, Fischer KD, Schuh AC, Schwartz L, Bernstein A \& Rossant J. A requirement for Flk1 in primitive and definitive hematopoiesis and vasculogenesis. Cell 199789 981-990. (https://doi.org/10.1016/s0092-8674(00)80283-4)

24 Kouskoff V, Lacaud G, Schwantz S, Fehling HJ \& Keller G. Sequential development of hematopoietic and cardiac mesoderm during embryonic stem cell differentiation. PNAS 2005102 13170-13175. (https://doi.org/10.1073/pnas.0501672102)

25 Kennedy M, D'Souza SL, Lynch-Kattman M, Schwantz S \& Keller G. Development of the hemangioblast defines the onset of hematopoiesis in human ES cell differentiation cultures. Blood 2007 109 2679-2687. (https://doi.org/10.1182/blood-2006-09-047704)

26 Murry CE \& Keller G. Differentiation of embryonic stem cells to clinically relevant populations: lessons from embryonic development. Cell 2008132 661-680. (https://doi.org/10.1016/j. cell.2008.02.008)

27 Choi KD, Yu J, Smuga-Otto K, Salvagiotto G, Rehrauer W, Vodyanik M, Thomson J \& Slukvin I. Hematopoietic and endothelia differentiation of human induced pluripotent stem cells. Stem Cells 200927 559-567. (https://doi.org/10.1634/stemcells.2008-0922)

28 Patsch C, Challet-Meylan L, Thoma EC, Urich E, Heckel T, O'Sullivan JF, Grainger SJ, Kapp FG, Sun L, Christensen K, et al. Generation of vascular endothelial and smooth muscle cells from human pluripotent stem cells. Nature Cell Biology 201517 994-1003. (https://doi.org/10.1038/ncb3205)

29 Vodyanik MA, Yu J, Zhang X, Tian S, Stewart R, Thomson JA \& Slukvin II. A mesoderm-derived precursor for mesenchymal stem and endothelial cells. Cell Stem Cell 20107 718-729. (https://doi. $\operatorname{org} / 10.1016 /$ j.stem.2010.11.011)

30 Kumar A, D'Souza SS, Moskvin OV, Toh H, Wang B, Zhang J, Swanson S, Guo LW, Thomson JA \& Slukvin II. Specification and diversification of pericytes and smooth muscle cells from Mesenchymoangioblasts. Cell Reports 201719 1902-1916. (https:// doi.org/10.1016/j.celrep.2017.05.019)

31 Lee G, Kim H, Elkabetz Y, Al Shamy G, Panagiotakos G, Barberi T, Tabar V \& Studer L. Isolation and directed differentiation of neural crest stem cells derived from human embryonic stem cells. Nature Biotechnology 200725 1468-1475. (https://doi.org/10.1038/nbt1365)

32 Jiang X, Gwye Y, McKeown SJ, Bronner-Fraser M, Lutzko C \& Lawlor ER. Isolation and characterization of neural crest stem cells derived from in vitro-differentiated human embryonic stem cells. Stem Cells and Development 200918 1059-1070. (https://doi. org/10.1089/scd.2008.0362)

33 Wang A, Tang Z, Li X, Jiang Y, Tsou DA \& Li S. Derivation of smooth muscle cells with neural crest origin from human induced pluripotent stem cells. Cells, Tissues, Organs 2012195 5-14. (https:// doi.org/10.1159/000331412)

34 Cheung C, Bernardo AS, Trotter MWB, Pedersen RA \& Sinha S. Generation of human vascular smooth muscle subtypes provides insight into embryological origin-dependent disease susceptibility. Nature Biotechnology 201230 165-173. (https://doi.org/10.1038/ nbt.2107)

35 Cheung C, Bernardo AS, Pedersen RA \& Sinha S. Directed differentiation of embryonic origin-specific vascular smooth muscle subtypes from human pluripotent stem cells. Nature Protocols 20149 929-938. (https://doi.org/10.1038/nprot.2014.059)

36 Jiao J, Xiong W, Wang L, Yang J, Qiu P, Hirai H, Shao L, Milewicz D, Chen YE \& Yang B. Differentiation defect in neural crest-derived smooth muscle cells in patients with aortopathy associated with bicuspid aortic valves. EBioMedicine 201610 282-290. (https://doi. org/10.1016/j.ebiom.2016.06.045)

37 Wanjare M, Kuo F \& Gerecht S. Derivation and maturation of synthetic and contractile vascular smooth muscle cells from human pluripotent stem cells. Cardiovascular Research 201397 321-330. (https://doi.org/10.1093/cvr/cvs315)

38 Eoh JH, Shen N, Burke JA, Hinderer S, Xia Z, Schenke-Layland K \& Gerecht S. Enhanced elastin synthesis and maturation in human vascular smooth muscle tissue derived from induced-pluripotent stem cells. Acta Biomaterialia 201752 49-59. (https://doi. org/10.1016/j.actbio.2017.01.083)

39 Wanjare M, Kusuma S \& Gerecht S. Perivascular cells in blood vesse regeneration. Biotechnology Journal 20138 434-447. (https://doi. org/10.1002/biot.201200199)

40 Wanjare M, Kusuma S \& Gerecht S. Defining differences among perivascular cells derived from human pluripotent stem cells. Stem Cell Reports 20142 561-575. (https://doi.org/10.1016/j. stemcr.2014.03.004)

41 Biel NM, Santostefano KE, DiVita BB, El Rouby N, Carrasquilla SD, Simmons C, Nakanishi M, Cooper-DeHoff RM, Johnson JA \& Terada N. Vascular smooth muscle cells from hypertensive patientderived induced pluripotent stem cells to advance hypertension pharmacogenomics. Stem Cells Translational Medicine 20154 1380-1390. (https://doi.org/10.5966/sctm.2015-0126)

42 Halaidych OV, Cochrane A, van den Hil FE, Mummery CL \& Orlova VV. Quantitative analysis of intracellular Ca2+ release and contraction in hiPSC-derived vascular smooth muscle cells. Stem Cell Reports 201912 647-656. (https://doi.org/10.1016/j. stemcr.2019.02.003)

43 Dash BC, Levi K, Schwan J, Luo J, Bartulos O, Wu H, Qiu C, Yi T, Ren Y, Campbell S, et al. Tissue-engineered vascular rings from human iPSC-derived smooth muscle cells. Stem Cell Reports 20167 19-28. (https://doi.org/10.1016/j.stemcr.2016.05.004)

44 Granata A, Serrano F, Bernard WG, McNamara M, Low L, Sastry P $\&$ Sinha S. An iPSC-derived vascular model of Marfan syndrome identifies key mediators of smooth muscle cell death. Nature Genetics 201749 97-109. (https://doi.org/10.1038/ng.3723)

45 Kilpinen H, Goncalves A, Leha A, Afzal V, Alasoo K, Ashford S, Bala S, Bensaddek D, Casale FP, Culley OJ, et al. Common genetic variation drives molecular heterogeneity in human iPSCs. Nature 2017546 370-375. (https://doi.org/10.1038/nature22403)

46 Collado MS, Cole BK, Figler RA, Lawson M, Manka D, Simmers MB, Hoang S, Serrano F, Blackman BR, Sinha S, et al. Exposure of induced pluripotent stem cell-derived vascular endothelial and smooth muscle cells in coculture to hemodynamics induces primary vascular cell-like phenotypes. Stem Cells Translational Medicine 20176 1673-1683. (https://doi.org/10.1002/sctm.17-0004)

47 Zhang J, Lian Q, Zhu G, Zhou F, Sui L, Tan C, Mutalif RA, Navasankari R, Zhang Y, Tse H-F, et al. A human iPSC model of Hutchinson Gilford progeria reveals vascular smooth Muscleand mesenchymal stem cell defects. Stem Cells 20118 31-45. (https://doi. org/10.1016/j.stem.2010.12.002) 
48 Atchison L, Zhang H, Cao K \& Truskey GA. A tissue engineered blood vessel model of Hutchinson-Gilford progeria syndrome using human iPSC-derived smooth muscle cells. Scientific Reports $2017 \mathbf{7} 8168$. (https://doi.org/10.1038/s41598-017-08632-4)

49 Ling C, Liu Z, Song M, Zhang W, Wang S, Liu X, Ma S, Sun S, Fu L, Chu $\mathrm{Q}$, et al. Modeling CADASIL vascular pathologies with patientderived induced pluripotent stem cells. Protein and Cell 201910 249-271. (https://doi.org/10.1007/s13238-019-0608-1)

50 Kelleher J, Dickinson A, Cain S, Hu Y, Bates N, Harvey A, Ren J, Zhang W, Moreton FC, Muir KW, et al. Patient-specific iPSC model of a genetic vascular dementia syndrome reveals failure of mural cells to stabilize capillary structures. Stem Cell Reports 201913 817-831. (https://doi.org/10.1016/j.stemcr.2019.10.004)

51 Cheung C, Goh YT, Zhang J, Wu C \& Guccione E. Modeling cerebrovascular pathophysiology in amyloid- $\beta$ metabolism using neural-crest-derived smooth muscle cells. Cell Reports 20149 391-401. (https://doi.org/10.1016/j.celrep.2014.08.065)

52 He J, Weng Z, Wu SCM \& Boheler KR. Generation of induced pluripotent stem cells from patients with COL3A1 mutations and differentiation to smooth muscle cells for ECM-surfaceome analyses. Methods in Molecular Biology 20181722 261-302. (https://doi. org/10.1007/978-1-4939-7553-2_17)

53 Boheler KR. Understanding vascular Ehlers-Danlos syndrome. Impact 20182018 29-31. (https://doi.org/10.21820/23987073.2018.3.29)

54 Cukierman E, Pankov R, Stevens DR \& Yamada KM. Taking cellmatrix adhesions to the third dimension. Science 2001294 1708-1712. (https://doi.org/10.1126/science.1064829)

55 Doyle AD \& Yamada KM. Mechanosensing via cell-matrix adhesions in 3D microenvironments. Experimental Cell Research 2016343 60-66. (https://doi.org/10.1016/j.yexcr.2015.10.033)

56 Grayson WL, Ma T \& Bunnell B. Human mesenchymal stem cells tissue development in 3D PET matrices. Biotechnology Progress 2004 20 905-912. (https://doi.org/10.1021/bp034296z)

57 Ravi M, Paramesh V, Kaviya SR, Anuradha E \& Solomon FDP. 3D cell culture systems: advantages and applications. Journal of Cellular Physiology 2015230 16-26. (https://doi.org/10.1002/jcp.24683)

58 Dahl SLM, Kypson AP, Lawson JH, Blum JL, Strader JT, Li Y, Manson RJ, Tente WE, DiBernardo L, Hensley MT, et al. Readily available tissue-engineered vascular grafts. Science Translational Medicine 20113 68ra9. (https://doi.org/10.1126/ scitranslmed.3001426)

59 Song H-HG, Rumma RT, Ozaki CK, Edelman ER \& Chen CS. Vascular tissue engineering: progress, challenges, and clinical promise. Cell Stem Cell 201822 340-354. (https://doi.org/10.1016/j. stem.2018.02.009)

60 Nakayama KH, Joshi PA, Lai ES, Gujar P, Joubert LM, Chen B \& Huang NF. Bilayered vascular graft derived from human induced pluripotent stem cells with biomimetic structure and function. Regenerative Medicine 201510 745-755. (https://doi.org/10.2217/ rme.15.45)

61 Gao L, Kupfer ME, Jung JP, Yang L, Zhang P, Da Sie Y, Tran Q, Ajeti V, Freeman BT, Fast VG, et al. Myocardial tissue engineering with cells derived from human-induced pluripotent stem cells and a native-like, high-resolution, 3-dimensionally printed scaffold. Circulation Research 2017120 1318-1325. (https://doi.org/10.1161/ CIRCRESAHA.116.310277)

$62 \mathrm{Hu}$ J, Wang Y, Jiao J, Liu Z, Zhao C, Zhou Z, Zhang Z, Forde K, Wang L, Wang J, et al. Patient-specific cardiovascular progenitor cells derived from integration-free induced pluripotent stem cells for vascular tissue regeneration. Biomaterials 201573 51-59. (https://doi. org/10.1016/j.biomaterials.2015.09.008)

63 Bargehr J, Low L, Cheung C, Bernard WG, Iyer D, Bennett MR, Gambardella L \& Sinha S. Embryological origin of human smooth muscle cells influences their ability to support endothelial network formation. Stem Cells Translational Medicine 20165 946-959. (https:// doi.org/10.5966/sctm.2015-0282)
64 Ren X, Moser PT, Gilpin SE, Okamoto T, Wu T, Tapias LF, Mercier FE, Xiong L, Ghawi R, Scadden DT, et al. Engineering pulmonary vasculature in decellularized rat and human lungs. Nature Biotechnology 201533 1097-1102. (https://doi.org/10.1038/nbt.3354)

65 Masumoto H, Nakane T, Tinney JP, Yuan F, Ye F, Kowalski WJ, Minakata K, Sakata R, Yamashita JK \& Keller BB. The myocardial regenerative potential of three-dimensional engineered cardiac tissues composed of multiple human iPS cell-derived cardiovascular cell lineages. Scientific Reports 20166 29933. (https://doi.org/10.1038/ srep29933)

66 Zhang B, Korolj A, Lai BFL \& Radisic M. Advances in organ-on-a-chip engineering. Nature Reviews Materials 20183 257-278. (https://doi. org/10.1038/s41578-018-0034-7)

67 Ribas J, Sadeghi H, Manbachi A, Leijten J, Brinegar K, Zhang YS Ferreira L \& Khademhosseini A. Cardiovascular organ-on-a-chip platforms for drug discovery and development. Applied In Vitro Toxicology 20162 82-96. (https://doi.org/10.1089/aivt.2016.0002)

68 Ribas J, Zhang YS, Pitrez PR, Leijten J, Miscuglio M, Rouwkema J, Dokmeci MR, Nissan X, Ferreira L \& Khademhosseini A. Biomechanical strain exacerbates inflammation on a progeria-ona-chip model. Small 201713 1603737. (https://doi.org/10.1002/ smll.201603737)

69 Kusuma S, Shen YI, Hanjaya-Putra D, Mali P, Cheng L \& Gerecht S. Self-organized vascular networks from human pluripotent stem cells in a synthetic matrix. PNAS 2013110 12601-12606. (https://doi. org/10.1073/pnas.1306562110)

70 Bye CR, Jönsson ME, Björklund A, Parish CL \& Thompson LH. Transcriptome analysis reveals transmembrane targets on transplantable midbrain dopamine progenitors. PNAS 2015112 E1946-E1955. (https://doi.org/10.1073/pnas.1501989112)

71 Gundry RL, Burridge PW \& Boheler KR. Pluripotent stem cell heterogeneity and the evolving role of proteomic technologies in stem cell biology. Proteomics 201111 3947-3961. (https://doi. org/10.1002/pmic.201100100)

72 Vanlandewijck M, He L, Mäe MA, Andrae J, Ando K, Del Gaudio F, Nahar K, Lebouvier T, Laviña B, Gouveia L, et al. A molecular atlas of cell types and zonation in the brain vasculature. Nature $2018 \mathbf{5 5 4}$ 475-480. (https://doi.org/10.1038/nature25739)

73 Liu M, Gomez D. Smooth muscle cell phenotypic diversity. Arteriosclerosis, Thrombosis, and Vascular Biology 201939 1715-1723. (https://doi.org/10.1161/ATVBAHA.119.312131)

74 da Cunha JPC, Galante PAF, de Souza JE, de Souza RF, Carvalho PM, Ohara DT, Moura RP, Oba-Shinja SM, Marie SKN, Silva WA, et al. Bioinformatics construction of the human cell surfaceome. PNAS 2009106 16752-16757. (https://doi.org/10.1073/pnas.0907939106)

75 Boheler KR, Bhattacharya S, Kropp EM, Chuppa S, Riordon DR, Bausch-Fluck D, Burridge PW, Wu JC, Wersto RP, Chan GCF, et al. A human pluripotent stem cell surface $\mathrm{N}$-glycoproteome resource reveals markers, extracellular epitopes, and drug targets. Stem Cell Reports 20143 185-203. (https://doi.org/10.1016/j. stemcr.2014.05.002)

76 Wollscheid B, Bausch-Fluck D, Henderson C, O'Brien R, Bibel M, Schiess R, Aebersold R \& Watts JD. Mass-spectrometric identification and relative quantification of N-linked cell surface glycoproteins. Nature Biotechnology 200927 378-386. (https://doi.org/10.1038/ nbt.1532)

77 Boheler KR \& Gundry RL. Concise review: cell surface N-linked glycoproteins as potential stem cell markers and drug targets. Stem Cells Translational Medicine 20176 131-138. (https://doi.org/10.5966/ sctm.2016-0109)

78 Gundry RL, Boheler KR, Van Eyk JE \& Wollscheid B. A novel role for proteomics in the discovery of cell-surface markers on stem cells: scratching the surface. Proteomics: Clinical Applications 20082 892-903. (https://doi.org/10.1002/prca.200780122)

79 Yan B, Wang P, Wang J \& Boheler KR. Discovery of surface target proteins linking drugs, molecular markers, gene regulation, protein

This work is licensed under a Creative Commons Attribution-NonCommercial 4.0 International License. Lioscientifica com at $04 / 26 / 2023$ 11:42:04AM 
networks, and disease by using a web-based platform targets-search. Methods in Molecular Biology 20181722 331-344. (https://doi. org/10.1007/978-1-4939-7553-2_19)

80 Bausch-Fluck D, Hofmann A, Bock T, Frei AP, Cerciello F, Jacobs A, Moest H, Omasits U, Gundry RL, Yoon C, et al. A mass spectrometricderived cell surface protein atlas. PLoS ONE 201510 e0121314. (https://doi.org/10.1371/journal.pone.0121314)

81 Marzi J, Brauchle EM, Schenke-Layland K \& Rolle MW. Non-invasive functional molecular phenotyping of human smooth muscle cells utilized in cardiovascular tissue engineering. Acta Biomaterialia 2019 89 193-205. (https://doi.org/10.1016/j.actbio.2019.03.026)

82 Lacolley P, Regnault V, Segers P \& Laurent S. Vascular smooth muscle cells and arterial stiffening: relevance in development, aging, and disease. Physiological Reviews 201797 1555-1617. (https://doi. org/10.1152/physrev.00003.2017)

83 Humphrey JD, Schwartz MA, Tellides G \& Milewicz DM. Role of mechanotransduction in vascular biology: focus on thoracic aortic aneurysms and dissections. Circulation Research 2015116 1448-1461. (https://doi.org/10.1161/CIRCRESAHA.114.304936)

84 Frank M, Albuisson J, Ranque B, Golmard L, Mazzella JM, BalTheoleyre L, Fauret AL, Mirault T, Denarié N, Mousseaux E, et al. The type of variants at the COL3A1 gene associates with the phenotype and severity of vascular Ehlers-Danlos syndrome. European Journal of Human Genetics 201523 1657-1664. (https://doi.org/10.1038/ ejhg.2015.32)

85 Morissette R, Schoenhoff F, Xu Z, Shilane DA, Griswold BF, Chen W, Yang J, Zhu J, Fert-Bober J, Sloper L, et al. Transforming growth factor- $\beta$ and inflammation in vascular (type IV) Ehlers-Danlos syndrome. Circulation: Cardiovascular Genetics 20147 80-88. (https:// doi.org/10.1161/CIRCGENETICS.113.000280)

86 Matthys OB, Hookway TA \& McDevitt TC. Design principles for engineering of tissues from human pluripotent stem cells. Current Stem Cell Reports 20162 43-51. (https://doi.org/10.1007/s40778-0160030-z)

87 Clevers H. Modeling development and disease with organoids. Cell 2016165 1586-1597. (https://doi.org/10.1016/j.cell.2016.05.082)

88 Hinson JT, Chopra A, Nafissi N, Polacheck WJ, Benson CC, Swist S, Gorham J, Yang L, Schafer S, Sheng CC, et al. HEART DISEASE. Titin mutations in iPS cells define sarcomere insufficiency as a cause of dilated cardiomyopathy. Science 2015349 982-986. (https://doi. org/10.1126/science.aaa5458)

89 Boudou T, Legant WR, Mu A, Borochin MA, Thavandiran N, Radisic M, Zandstra PW, Epstein JA, Margulies KB \& Chen CS. A microfabricated platform to measure and manipulate the mechanics of engineered cardiac microtissues. Tissue Engineering: Part A 201218 910-919. (https://doi.org/10.1089/ten.tea.2011.0341)

90 Liu AS, Wang H, Copeland CR, Chen CS, Shenoy VB \& Reich DH. Matrix viscoplasticity and its shielding by active mechanics in microtissue models: experiments and mathematical modeling. Scientific Reports 20166 33919. (https://doi.org/10.1038/srep33919)

91 Ayoubi S, Sheikh SP \& Eskildsen TV. Human induced pluripotent stem cell-derived vascular smooth muscle cells: differentiation and therapeutic potential. Cardiovascular Research 2017113 1282-1293. (https://doi.org/10.1093/cvr/cvx125)

92 Shen EM \& McCloskey KE. Development of mural cells: From in vivo understanding to in vitro recapitulation. Stem Cells and Development 201726 1020-1041. (https://doi.org/10.1089/scd.2017.0020)

93 Generali M, Casanova EA, Kehl D, Wanner D, Hoerstrup SP, Cinelli P \& Weber B. Autologous endothelialized small-caliber vascular grafts engineered from blood-derived induced pluripotent stem cells. Acta Biomaterialia 201997 333-343. (https://doi.org/10.1016/j. actbio.2019.07.032)

94 Zhu Y, Li X, Janairo RRR, Kwong G, Tsou AD, Chu JS, Wang A, Yu J, Wang D \& Li S. Matrix stiffness modulates the differentiation of neural crest stem cells in vivo. Journal of Cellular Physiology $20192 \mathbf{2 3 4}$ 7569-7578. (https://doi.org/10.1002/jcp.27518)

95 Luo J, Qin L, Kural MH, Schwan J, Li X, Bartulos O, Cong XQ, Ren Y, Gui L, Li G, et al. Vascular smooth muscle cells derived from inbred swine induced pluripotent stem cells for vascular tissue engineering. Biomaterials 2017147 116-132. (https://doi.org/10.1016/j. biomaterials.2017.09.019)

96 Moldovan L, Barnard A, Gil CH, Lin Y, Grant MB, Yoder MC, Prasain N \& Moldovan NI. iPSC-derived vascular cell spheroids as building blocks for scaffold-free biofabrication. Biotechnology Journal 201712 1700444. (https://doi.org/10.1002/biot.201700444)

97 Gui L, Dash BC, Luo J, Qin L, Zhao L, Yamamoto K, Hashimoto T, Wu H, Dardik A, Tellides G, et al. Implantable tissue-engineered blood vessels from human induced pluripotent stem cells. Biomaterials 2016 102 120-129. (https://doi.org/10.1016/j.biomaterials.2016.06.010)

98 Hibino N, Duncan DR, Nalbandian A, Yi T, Qyang Y, Shinoka T \& Breuer CK. Evaluation of the use of an induced puripotent stem cell sheet for the construction of tissue-engineered vascular grafts. Journal of Thoracic and Cardiovascular Surgery 2012143 696-703. (https://doi. org/10.1016/j.jtcvs.2011.06.046)

99 Xie C, Hu J, Ma H, Zhang J, Chang LJ, Chen YE \& Ma PX. Threedimensional growth of iPS cell-derived smooth muscle cells on nanofibrous scaffolds. Biomaterials 201132 4369-4375. (https://doi. org/10.1016/j.biomaterials.2011.02.049)

Received in final form 7 November 2019

Accepted 12 December 2019

Accepted Preprint published online 12 December 2019 (c) 2020 The authors Published by Bioscientifica Ltd

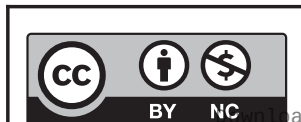

This work is licensed under a Creative Commons Attribution-NonCommercial 4.0 International License.

ded from Bioscientifica.com at 04/26/2023 11:42:04AM 